\title{
Towards the Other Side of Complexity: Values and Decisions in a Time of Uncertainty
}

\author{
Marcelo Knobel
}

Humanity is experiencing a moment of great uncertainty. This is not the first time a pandemic threatens the lives of millions of people. However, the speed with which governments and scientists are reacting to events is unprecedented. In an incredibly short time after the discovery of the virus, public health measures were implemented, and the development of defences in the form of public policies, medical therapies, and vaccines began. At this precarious moment, when the proliferation of information (and misinformation) from a variety of sources contribute to the spread of panic, universities and the scientific community emerge as the best and most reliable sources of information. It is only highly qualified specialists who can truly address the pandemic and its terrible economic, political, and public health consequences.

Paradoxically, this pandemic has been a game changer in terms of the public perception of higher education institutions (HEI), which have lately been under constant attack in many countries. In Brazil, for example, there is an agenda to discredit public universities and the sciences through fake news and undermine them through budget cuts. The current crisis now underscores the importance of research universities and institutes for the future of the country and the world to face this and future threats.

While the importance of higher education is starting to be appreciated again, HEIs still face major internal challenges and new problems every day. Even without clear answers, decisions must be made, and one will only know in the future how to assess these decisions.

In fact, as I am writing this text, the future is very uncertain. During this world crisis caused by the coronavirus pandemic, the outlook has become even more nebulous. Today, we simply do not know how or when the Covid19 pandemic will end or how it will change the way we live on our planet. Even with so many uncertainties,

\footnotetext{
M. Knobel ( $\varangle)$

University of Campinas (Unicamp), Campinas, Brazil

e-mail: knobel@unicamp.br 
universities must respond and keep moving. Leadership in HEI must still make complex decisions and provide answers on a daily basis. The best way to proceed is by allowing the mission of the institution to serve as the main compass while considering the needs of all of the people it serves.

As we are now in the middle of the pandemic and full of uncertainties, each decision taken by the leadership can have important consequences, ranging from the livelihood and well-being of the community to the long-term survival of the institution. These decisions are more and more complex because there are so many sources of information with equally conflicting conclusions as James O'Toole has pointed out:

Today's problems are also complexly interrelated and, thus, build demonically on each other. The challenge of coping with these problems is compounded by two paradoxical trends: an implosion of the speed of global communication and a simultaneous centrifugal explosion of information. These trends conspire to make managers increasingly interdependent while affording them the data to make more independent decisions. As if that weren't enough recipe for conflict and confusion, today we all feel entitled to a say in dealing with the problems that affect us all. (O'Toole 1995: 4).

When dealing with such complex issues, it is important to be pragmatic and look for straightforward solutions that rely on basic, fundamental concepts:

The simplicity on the other side of complexity offers a different prospect: that incompatible values might be made mutually achievable and reinforcing. The leadership challenge, then, is to get to the other side of complexity. But how does one get there? Only one sure route has been identified: the enhancement of understanding. To move beyond the confusion of complexity, executives must abandon their constant search for the immediately practical, and, paradoxically, seek to understand the underlying ideas and values that have shaped the world they work in. (O'Toole 1995:7).

This is why it is so important to focus on the mission of the institution, especially when the future is undetermined. The mission, on the other hand, must be rooted in values, which are essential for any institution. The values are fundamental to deal with any sort of challenge, as they offer HEIs guidance for their behaviour and decision-making process. Some values define the core of the idea of a university, such as autonomy and academic freedom (and in recent times underlined by the Magna Charta Universitatum $^{1}$ ). There are many other values as well that are critical to helping HEIs understand and define themselves, such as social responsibility, diversity, excellence, and other principles specific to institutional missions. To expand public trust in universities amid today's complexity and uncertainty, HEIs need to explicitly define and communicate their values while demonstrating that their values inform practice and decision-making processes. In fact, a well-established mission, based on consolidated values, is the only safe guide for these unclear times.

The challenges ahead are not new to universities. They come in different forms and velocity, and they come as part of political, sanitary, and economic crises. As mentioned, in order for universities to tackle the question of how to face the challenges at hand, we must return to the basic problems that lie behind the current pandemic. In

\footnotetext{
${ }^{1}$ See http://www.magna-charta.org/.
} 
a wonderful speech given by Julián Marías, on the occasion of the 4th centenary of San Marcos University (Lima, Peru), titled "The University, Problematic Reality", Marías claims (Marías 1953, p. 61):

I know of no other way to solve problems than to use them as a starting point: the only way to overcome difficulties is to rest on them to jump upwards. For this reason, what most urges the university on is to penetrate its inner problematic condition. To be a university student today is only possible with a dose of uneasiness, I would even say a certain state of mind... But this uneasiness can also be a form of salvation; its prime consequence is to avoid inertia, to avoid carrying on with the usual, as if it were justified and obvious; the second is to eliminate petulance and easy satisfaction, to replace them with the most fruitful characteristic available to man: discontent. The current university student must understand that his studies are not the only or most important thing, that he must not be certain of exactly what to do, that his mission is more than doubtful, and that he must carry it out with proud modesty."

The idea here, as antiquated as it may sound, is that difficult times can indeed serve as an opportunity for positive and needed transformation. To do so, we need to step forward, and demand of society to help with this huge challenge. Again Marías (Marías 1953, p. 63):

Faced with all difficulties, this state of mind can be comforting: this is why I spoke [...] of proud modesty. Isn't this an undertaking worthy of the University, with its glorious history of seven centuries, to recreate itself within these narrow delimitations? The University has its back against the wall: the best situation to fight. It is the right moment to assert the university scholars' claim and status, in all its aspects. We all have been informed and formed by the University, we will always be universitas magistrorum et scholarium, in whatever locus the authentic form of that belonging may be."4

HEIs have a commitment to students and their families and to the larger society that finances them. Perhaps most importantly, they must provide basic and applied research as well as direct medical assistance. Universities cannot fail to disseminate scientifically correct content and participate in campaigns to ensure that the population has timely, accurate information. As harsh as the forecasts are for the immediate

\footnotetext{
${ }^{2}$ La Universidad, Realidad Problemática, in Spanish.

3 "No conozco otro modo de resolver los problemas que partir de ellos: la única manera de superar las dificultades es apoyarse precisamente en ellas para brincar hacia lo alto. Por esto, lo que más urge a la Universidad es penetrarse de su condición problemática. Sólo es posible hoy ser universitario con cierta intranquilidad, yo diría hasta de conciencia. Esa inquietud puede ser salvadora; su primera consecuencia es evitar la inercia, el hacer lo de siempre, como si estuviese justificado y fuese obvio; la segunda, eliminar la petulancia y la fácil satisfacción, para sustituirlas por lo más fecundo de que dispone el hombre: el descontento. El universitario actual debe pensar que no es lo único ni lo más importante, que no sabe bien qué tiene que hacer, que su misión es más que dudosa, y realizarla con una orgullosa modéstia.

4 "Frente a todas las dificultades, esta conciencia puede ser confortadora: por eso hablaba unas líneas más arriba de orgullosa modestia. No es una empresa digna de la Universidad, de su gloriosa historia de siete siglos, recrearse de nuevo en estas estrechas circunstancias? La Universidad está entre la espada y la pared: la mejor situación para luchar. Y entonces conviene reivindicar, en todas sus formas, la condición de universitarios. Lo somos todos los que hemos sido informados y conformados por la Universidad, los que pertenecemos para siempre a aquellas universitas magistrorum et scholarium, sea cualquiera el lugar donde nos sitúe la forma auténtica de esa pertenencia.
} 
future, universities will be up to the challenge. In such a complex atmosphere, their focus must continue to be their mission, and they must make every effort to demonstrate to the society that sustains them that their primary role is the well-being of that very society.

Higher education institutions have a duty to continue their activities, despite the restrictions that the current situation imposes. They represent a huge social investment that cannot be overlooked or minimized. Now, more than ever, they must make it clear that this long-term investment is fundamental to a better future for all.

\section{References}

Marías, J. (1953). La Universidad, Realidad Problemática. Cruz del Sur (Santiago de Chile). Retreived from: http://www.educacionyfp.gob.es/dctm/revista-de-educacion/1952/ 195205/1952re05universidad.pdf?documentId=0901e72b81ee08a7 (28.08.2020).

O'Toole, J. (1995). The Executive's Compass: Business and the Good Society. Oxford University Press.

Marcelo Knobel is rector of the University of Campinas (Unicamp) and a member of the Board of Directors of the Brazilian Center for Research in Energy and Materials (CNPEM). A full professor of Physics, Knobel held several leadership roles at Unicamp, including vice-rector for Undergraduate Programs. He also served as executive director of the Brazilian Nanotechnology National Laboratory (LNNano) at CNPEM. Knobel received both his bachelor's and his doctoral degrees in Physics from Unicamp, and was a post-doctoral researcher in Italy and Spain. He has published more than 250 scientific papers and numerous opinion pieces in newspapers and magazines.

Open Access This chapter is licensed under the terms of the Creative Commons Attribution 4.0 International License (http://creativecommons.org/licenses/by/4.0/), which permits use, sharing, adaptation, distribution and reproduction in any medium or format, as long as you give appropriate credit to the original author(s) and the source, provide a link to the Creative Commons license and indicate if changes were made.

The images or other third party material in this chapter are included in the chapter's Creative Commons license, unless indicated otherwise in a credit line to the material. If material is not included in the chapter's Creative Commons license and your intended use is not permitted by statutory regulation or exceeds the permitted use, you will need to obtain permission directly from the copyright holder.

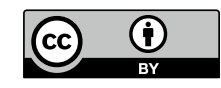

